\title{
Nitrogen and potassium supply and the morphogenic and productive characteristics of marandu palisadegrass
}

\author{
Marcio Mahmoud Megda ${ }^{1}$, Francisco Antonio Monteiro ${ }^{2}$ \\ ${ }^{1}$ Pós-Graduando em Solos e Nutrição de Plantas, ESALQ, Universidade de São Paulo, Caixa Postal 9, CEP: 13418-900, Piracicaba, São \\ Paulo, Brasil. Bolsista do CNPq. \\ ${ }^{2}$ Departamento de Ciência do Solo, ESALQ, Universidade de São Paulo, Caixa Postal 9, CEP: 13418-900, Piracicaba, São Paulo, Brasil. \\ Bolsista do CNPq.
}

ABSTRACT - The objective of this work was to study morphogenic characteristics, and dry matter production of roots and shoots of marandu palisadegrass (Brachiaria brizantha cv. Marandu) submitted to combinations of nitrogen and potassium, in a nutritive solution, employing silica as substrate. The experiment was carried out in a greenhouse during the summer. It was used a $5^{2}$ fractionated factorial scheme with 13 combinations of nitrogen and potassium, which were distributed in a randomized block design, with four replications. The nitrogen $\times$ potassium interaction was significant for the number of tillers and leaves, for leaf area, for shoots and root section dry mass, for total length and surface and specific length and surface in the roots. Production of aerial part dry mass positively correlated with the number of tillers and leaves and grass leaf area. Nitrogen rates modulated the root system development, and the root specific length and surface decreased when high rates of nitrogen and potassium were supllied. Nitrogen and potassium influence Marandu palisadegrass morphogenic characteristics, which are determinant for grass dry matter production.

Key Words: Brachiaria brizantha, leaf, nutrient solution, root, shoot, tiller

\section{Suprimento combinado de nitrogênio com potássio para o capim-marandu: características morfogênicas e produtivas}

\begin{abstract}
RESUMO - Objetivou-se estudar as características morfogênicas e a produção de massa seca da parte aérea e das raízes do capim-marandu (Brachiaria brizantha cv. Marandu) submetido a combinações de nitrogênio e potássio, em solução nutritiva, empregando-se sílica como substrato. O experimento foi realizado em casa de vegetação, no verão. Utilizou-se o esquema fatorial $5^{2}$ fracionado, com 13 combinações de nitrogênio e potássio, distribuídas em delineamento de blocos ao acaso, com quatro repetições. A interação nitrogênio $\times$ potássio foi significativa para número de perfilhos e de folhas, área foliar, massa seca da parte aérea e de raízes, comprimento e superfície totais e comprimento e superfície específicas nas raízes. A produção de massa seca da parte aérea correlacionou-se positivamente com número de perfilhos e de folhas e área foliar do capim. As doses de nitrogênio se mostraram moduladoras do desenvolvimento do sistema radicular e 0 comprimento e a superfície específicos diminuíram quando fornecidas altas doses desses nutrientes. O nitrogênio e o potássio influenciam as características morfogênicas do capim-marandu, que são determinantes da produção de massa seca da gramínea.
\end{abstract}

Palavras-chave: Brachiaria brizantha, folha, parte aérea, perfilho, raíz, solução nutritiva

\section{Introduction}

The food demand intensification requires an increase in pasture yield, which is the basic and the cheapest source of animal feeding. The use of fertilizers is, therefore, essential to achieve high productivity. In such scenario, nitrogen and potassium play a major role in the development of morphogenic characteristics and dry mass yield of forage grasses.

Nitrogen is usually the nutrient most extracted by plants from the soil, and it influences the number of tillers and leaves, and leaf area. It is also the nutrient which most influences the length, surface area and dry mass of the root system, therefore being a major factor in dry mass production.

Potassium is the second nutrient most extracted by plants, and it is related to the physiological and biochemical processes in plants, showing a positive synergistic effect on nitrogen plant nutrition.

Fertilization is essential to establish and maintain forage crops. Nitrogen and potassium supply increase yield of forage grasses as Vicente-Chandler et al. (1962), 
Carvalho et al. (1991), Monteiro et al. (1995), Ferragine \& Monteiro (1999), Lavres Jr. \& Monteiro (2002) and Lavres Jr. et al. (2004), among others, have demonstrated.

The influence of nutrients on morphogenic characteristics of forage grasses have been studied more frequently for nitrogen and, as highlighted by Chapman \& Lemaire (1993), there is a need to do the same for the other nutrients.

The objective of this work is to study the morphogenic characteristics and the yield of dry mass of shoots and roots, as well as to determine the combined rate of nitrogen and potassium that maximize the marandu palisadegrass yield.

\section{Material and Methods}

The experiment was carried out during the summer in a greenhouse located in Piracicaba, São Paulo, Brazil, using Brachiaria brizantha Stapf. cultivar Marandu. The plants were grown in 3.6 L plastic pots filled with silica as substrate. They were used to test combinations of five rates of nitrogen and five rates of potassium, in a fractionate $5^{2}$ factorial according to Littell \& Mott (1975). The 13 combinations of nitrogen and potassium in the nutrient solution were the following: (in $\mathrm{mmol} \mathrm{L}^{-1}$ ): 2.0 and $0.5 ; 2.0$ and $6.0 ; 2.0$ and $11.0 ; 8.0$ and $3.0 ; 8.0$ and $8.5 ; 15.0$ and $0.5 ; 15.0$ and $6.0 ; 15.0$ and $11.0 ; 24.0$ and $3.0 ; 24.0$ and 8.5; 33.0 and 0.5 ; 33.0 and 6.0 ; and 33.0 and 11.0. Other macronutrients ( $\mathrm{P}, \mathrm{Ca}, \mathrm{Mg}$ and $\mathrm{S}$ ) and micronutrients (B, $\mathrm{Cu}, \mathrm{Fe}, \mathrm{Mn}, \mathrm{Mo}$ and $\mathrm{Zn}$ ) were supplied according to Hoagland \& Arnon (1950) solution. The nutrient solutions were prepared by keeping the ratio nitrate: ammonium at 1.8:1.0 (64.4\% ${\mathrm{N}-\mathrm{NO}_{3} \text { - and 35.6\% N-NH}}_{4}^{+}$). Pots were arranged in a randomized block design, with four replications.

Grass seeds were put in plastic trays filled with sand washed in tap and distilled water. Trays were frequently irrigated with distilled water until transplanting of seedlings (15 in each pot) at $4 \mathrm{~cm}$ high, which occured after 16 days. After that, $1 \mathrm{~L}$ of diluted solutions was added to each pot during 3 days. The diluted solutions were prepared with each of the combined N-K ratios, diluted in 1/3 of their concentrations. From the fourth day on, the original concentrations were used.

Two evaluations were performed during the growing process of plants. The first harvest was done on day 46 after transplanting and the second harvest, on day 30 after the first harvest (day 76 after transplanting). Plant material was classified into four parts as emerging leaves, leaf blade of the two recently expanded leaves, leaf blades of mature leaves and of stalks + sheaths. The dry mass of this material was combined to achieve the shoot mass. The leaf area was measured immediately after the harvests in the three leaf groups. All this material was dried in a ventilated oven at $70^{\circ} \mathrm{C}$ and weighted when the mass was constant.

Only after the second harvest, roots were washed from the substrate using a set of two sieves with 1.00 and $0.25 \mathrm{~mm}$ apertures. According to Rossiello et al. (1995), a sub-sample of approximately $20 \%$ of the total roots volume of each plot was taken into plastic cups with distilled water and gentian violet at $50 \mathrm{~g} \mathrm{~L}^{-1}$ to dye the younger areas. Scans of that material were obtained and processed by the SIARCS (Integrated System for Root and Soil Cover Analysis), version 3.0 to obtain the length and surface area of the roots. Dry mass of root sub-samples were then obtained and the total length and total surface of the root system in each pot was estimated by proportionality. Specific length and specific surface were calculated by the ratio of these measurements to the dry mass (Crestana et al., 1994).

Statistical analysis was done using Statistical Analysis System (SAS, 1996), using 5\% significant level. For the significant interactions between nitrogen and potassium rates, a polynomial regression was calculated using the RSREG protocol, with response surface analysis. Points of maximal response for the nitrogen and potassium response were obtained directly from the SAS output. The study of the variable correlations was also carried out.

\section{Results and Discussion}

The nitrogen $\times$ potassium rates was significant for the total number of tillers at the first and second harvests of marandu palisadegrass. The greatest number of tillers was found for $29.69 \mathrm{mmol} \mathrm{L}^{-1}$ of nitrogen and $8.76 \mathrm{mmol} \mathrm{L}^{-1}$ of potassium in the first harvest and $28.98 \mathrm{mmol} \mathrm{L}^{-1}$ of nitrogen, and $9.43 \mathrm{mmol} \mathrm{L}^{-1}$ of potassium in the second harvest (Figure 1). Such combinations of nitrogen and potassium rates resulted in 40 tillers in the first harvest and 66 tillers in the second harvest.

The number of tillers was more influenced by nitrogen rates than by potassium rates. For example, for the first harvest, the number of tillers in the treatment with $2 \mathrm{mmol} \mathrm{L}^{-1}$ of nitrogen and $0.5 \mathrm{mmol} \mathrm{L}^{-1}$ of potassium was three times smaller than in the treatment with $33 \mathrm{mmol} \mathrm{L}^{-1}$ of nitrogen and $0.5 \mathrm{mmol} \mathrm{L}^{-1}$ of potassium, but it was almost the same in the treatment with $2 \mathrm{mmol} \mathrm{L}^{-1}$ of nitrogen and $11 \mathrm{mmol} \mathrm{L}^{-1}$ of potassium.

Ferragine \& Monteiro (1999) reported significant interaction for rates of nitrogen and rates of potassium as regarded to the number of tillers in the first harvest of Signal 
grass (Brachiaria decumbens Stapf.). They also found that the greatest number of tillers was observed at nitrogen rates of $17 ; 24$ and $34 \mathrm{mmol} \mathrm{L}^{-1}$, depending on the potassium rate. The increase in potassium rate in the nutrient solution resulted in smaller increase in the number of tillers than the increase in nitrogen rates.

Lavres Jr. \& Monteiro (2003) did not find significance for nitrogen and potassium supply for tillering of mombaçagrass (Panicum maximum Jacq.) at the first harvest. The relationship was fitted in a second degree polynomial, and the nitrogen rate to achieve the maximum number of tillers was $21.15 \mathrm{mmol} \mathrm{L}^{-1}$. For potassium, the maximum number of tillers for mombaçagrass was at $7.5 \mathrm{mmol} \mathrm{L}^{-1}$. These concentrations in the nutrient solution were greater than those recommended by Hoagland \&Arnon (1950).

The number of tillers was greater on the second harvest than on the first (Figure 1b) probably because of the greater consumption of plant resources to establish the root system and the shoot up to the first harvest. On the second harvest, the root system was already grown and absorbing nutrients, as well as the first harvest induced the basal buds to produce new tillers.

Greater number of tillers in the second harvest was also reported by Lavres Jr. \& Monteiro (2003), who observed a maximum number of tillers at the nitrogen rate of $24.42 \mathrm{mmol} \mathrm{L}^{-1}$ and potassium rate of $10.15 \mathrm{mmol} \mathrm{L}^{-1}$. These are also greater than those rates recommended by Hoagland \& Arnon (1950). Mattos \& Monteiro (1998) studied potassium rates in marandu palisadegrass and found 25 and 50 tillers in the first and second harvests,

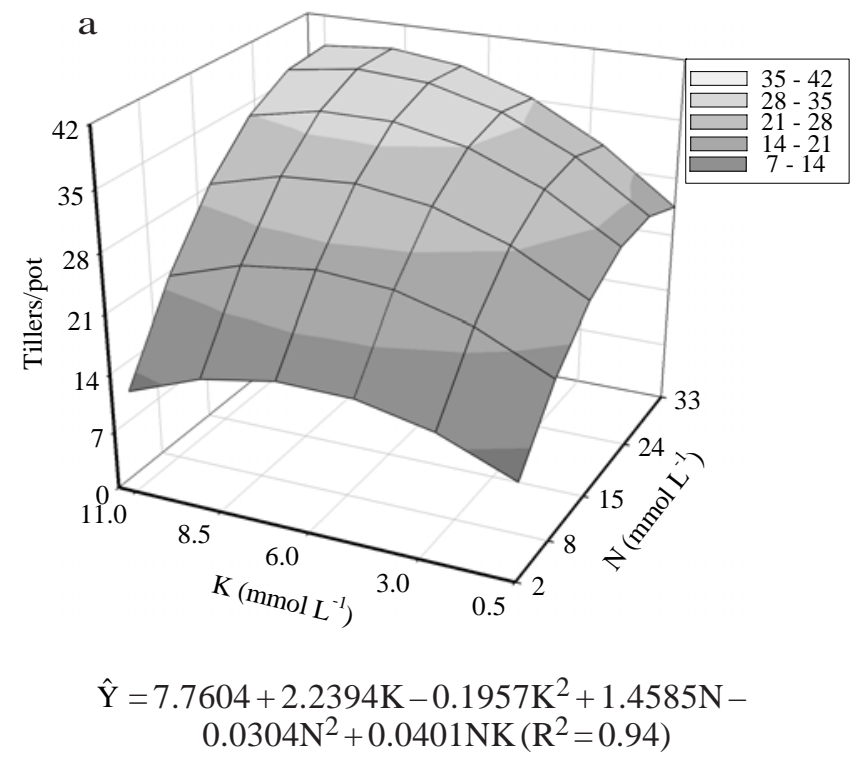

using a nitrogen rate of $15 \mathrm{mmol} \mathrm{L}^{-1}$ and a potassium rate of $12 \mathrm{mmol} \mathrm{L}^{-1}$.

Such results support the idea that the availability of nutrients influences the tillering of forage plants. Nitrogen effect depends on several factors such as light intensity, available water, and plant development at the time fertilizer application. Nitrogen should be available during the time the plant stimulates the growing sites to rebuild the shoot (Corsi, 1986). Tillering responds positively to nutrient application, and nitrogen is the nutrient which influences at most the population of tillers (Langer, 1963); Laude, 1972; Pinto et al., 1994; Mesquita et al., 2008). Increase in tillering impacts the pasture productivity because it enhaces the amount of dry mass per unit area and the ground occupation. Alexandrino et al. (2005) studied the growing, chemical and morphogenic characteristics of marandu palisadegrass using nitrogen rates and harvest times and observed a great variation of tillering along the sprout stage as influenced by nitrogen rates. Plants suppressed by nitrogen almost did not tillered.

Previous researchs highlighted the importance of nitrogen in tillering (Ryle, 1970; Nelson \& Zarrough, 1981; McKenzie, 1996; Mesquita et al. 2008) alone or coupled with light intensity (Auda et al., 1976). By studying Setaria anceps Stapf., Panicum maximum Jacq. and Andropogon gayanus L., Pinto et al. (1994) recommended increase of nitrogen rates from 15 to $90 \mathrm{mg} \mathrm{dm}^{-3}$ only for Setaria anceps Stapf.

The effect of nitrogen rates was significant for the total number of leaves during the first and the second harvests of marandu palisadegrass. The maximum number

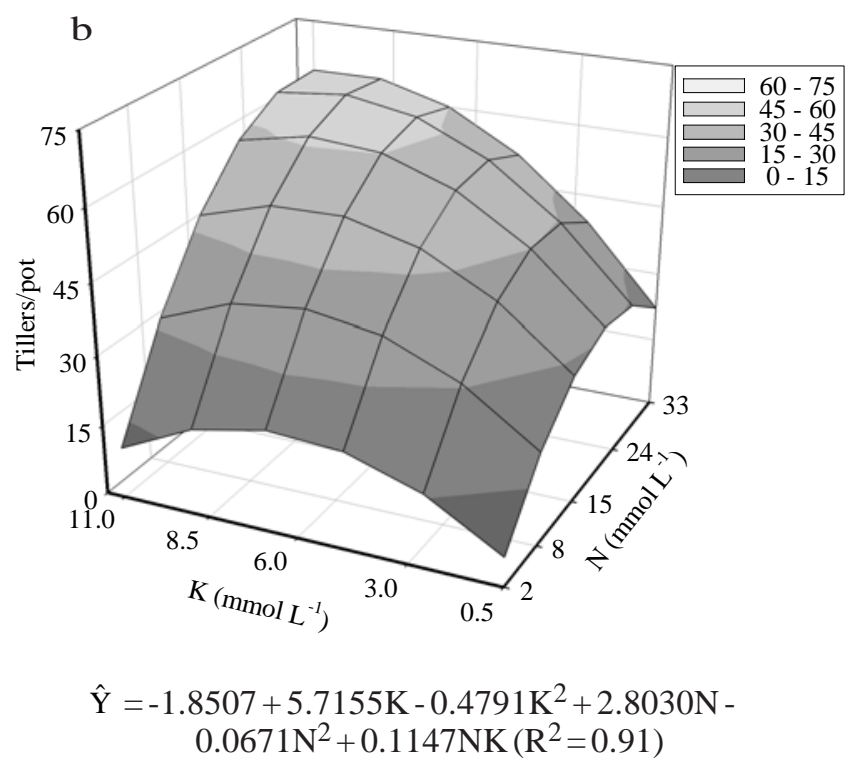

Figure 1 - Number of tillers per pot in the first (a) and second (b) harvests of marandu palisadegrass as related to combinations of nitrogen and potassium rates. 
of leaves was achieved for $28.38 \mathrm{mmol} \mathrm{L}^{-1}$ of nitrogen and $9.23 \mathrm{mmol} \mathrm{L}^{-1}$ of potassium in the first harvest (172 leaves) and $29.37 \mathrm{mmol} \mathrm{L}^{-1}$ of nitrogen and $8.83 \mathrm{mmol} \mathrm{L}^{-1}$ of potassium in the second harvest (253 leaves) (Figure 2). The greater number of leaves in the second harvest was related to the greater tillering in this stage. The correlation between the number of tillers and number of leaves resulted in $r=0.98^{* *}$ at the first harvest and $r=0.99 * *$ at the second harvest. When the nitrogen and potassium rates were combined to achieve the greatest number of leaves, a ratio of 4 leaves per tiller was shown.

In Figure 2, it can be observed that, by keeping the smallest potassium rate from the smallest to the greatest nitrogen rate, there is a $60 \%$ increase in the number of leaves. The opposite (keeping the smallest nitrogen rate from the smallest to the greatest potassium rate), the number of leaves was almost constant (40 leaves).

For Brachiaria decumbens Stapf., Ferragine et al. (2001) studied the number of green leaves in two harvests and concluded that the average number of leaves was significantly influenced by nitrogen rates during the two stages but not by the potassium rates neither by the nitrogen $\times$ potassium interaction. The greatest number of leaves was observed for nitrogen of $24 \mathrm{mmol} \mathrm{L}^{-1}$ in the first harvest and $21 \mathrm{mmol} \mathrm{L}^{-1}$ in the second harvest. Because the marandu palisadegrass is more demanding than Brachiaria decumbens Stapf., it required 16\% more nitrogen in the first harvest and $18 \%$ more in the second harvest to achieve the greatest number of leaves.

Ruggieri et al. (1994) studied the growing characteristics and dry mass production of Brachiaria brizantha

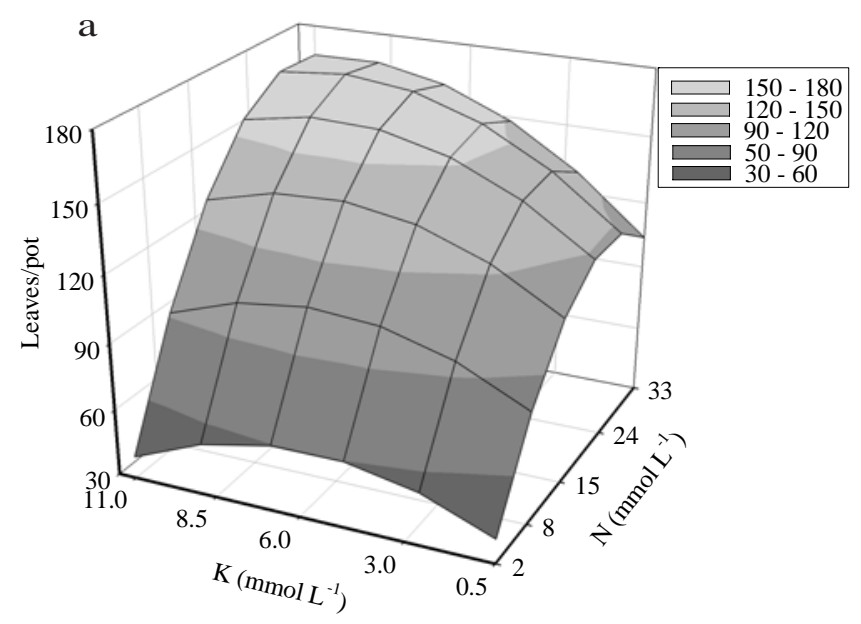

$$
\begin{gathered}
\hat{\mathrm{Y}}=21.8463+7.8801 \mathrm{~K}-0.7284 \mathrm{~K}^{2}+7.9384 \mathrm{~N}- \\
0.1717 \mathrm{~N}^{2}+0.1961 \mathrm{NK}\left(\mathrm{R}^{2}=0.95\right)
\end{gathered}
$$

Stapf. cv. Marandu as a function of ammonium nitrate application and harvest frequency and observed that the increase in nitrogen rates $\left(0 ; 33\right.$ and $\left.66 \mathrm{~kg} \mathrm{ha}^{-1}\right)$ increased the number of leaves. The authors highlighted that this increase might be related to the time of nitrogen application in relation to the harvests, possibly causing a benefit for the leaf growing as compared to the other plant parts.

Nabinger \& Medeiros (1995) hypothesized that nitrogen availability is the dominant factor for plant growing and development, particularly because of the faster growing of accessory buds and the starting of tillers, although such starting only occurs after the leaf area index is greater than a critical value, which depends on the amount of light that reaches the late buds. In such way, the environmental factors that can benefit the tillering when the plant cover is still not fully developed may become harmful when the plant cover is developed, since the leaf area index increases the tiller competition for light. Nitrogen deficiency results in greater number of dormant buds while the adequate nitrogen supply allows achieving its maximum during tillering.

Lavres Jr. \& Monteiro (2002) did not find significant nitrogen $\times$ potassium interaction in the first harvest. However, the leaf production was significant both for nitrogen rates (maximum at $23 \mathrm{mmol} \mathrm{L}^{-1}$ ) and potassium rates, fitting in a linear model. In the second harvest, the nitrogen $\times$ potassium interaction was significant and the maximum leaf production was achieved with rates higher than those studied. Nevertheless, the area of maximum production corresponded to the points of the nitrogen rate of $24 \mathrm{mmol} \mathrm{L}^{-1}$ and potassium of $8 \mathrm{mmol} \mathrm{L}^{-1}$. These authors also asserted that the rates of nitrogen and

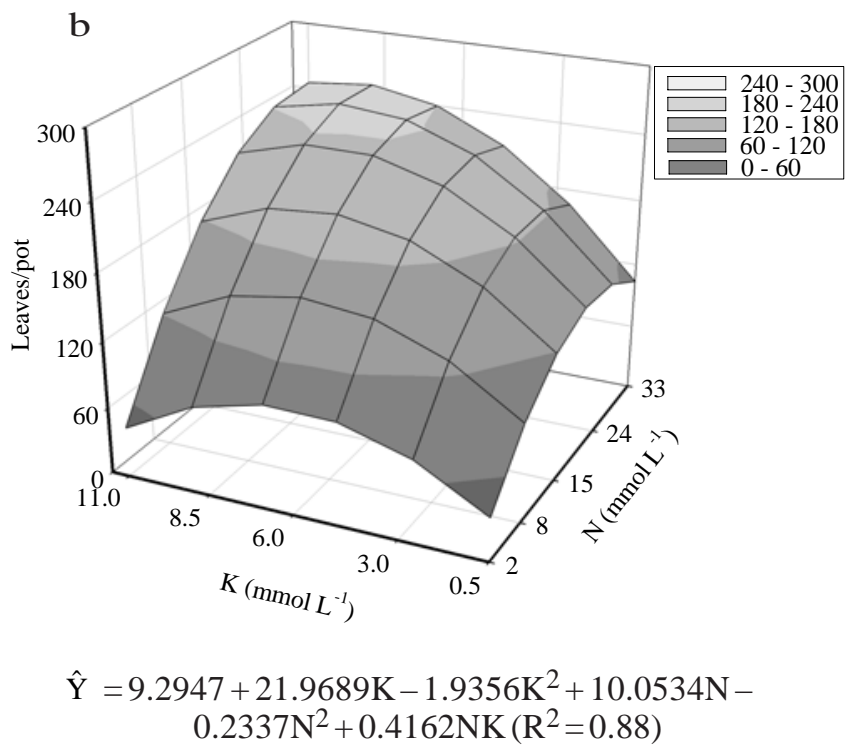

Figure 2 - Number of leaves per pot in the first (a) and second (b) harvests of marandu palisadegrass as related to combinations of nitrogen and potassium rates. 
potassium in the solution, according to Hoagland \& Arnon (1950), were not sufficient to result in maximum production of leaves.

In general, by comparing the nitrogen and potassium rates of Hoagland and Arnon (1950) with those of the present experiment, an increase of $15 \mathrm{mmol} \mathrm{L}^{-1}$ of nitrogen and $3 \mathrm{mmol} \mathrm{L}^{-1}$ of potassium can be suggested in order to achieve the maximum number of tillers and leaves. The rates of nitrogen and potassium that maximize the leaf area of marandu palisadegrass were $33 \mathrm{mmol} \mathrm{L}^{-1}$ of nitrogen and $11 \mathrm{mmol} \mathrm{L}^{-1}$ of potassium, both in the first and second harvests.

The change in leaf area of marandu palisadegrass as a function of nitrogen and potassium rates fitted a polynomial model (Figure 3). In the first harvest, the leaf area was 22.5 times smaller in the minimum concentration of nitrogen and potassium than that in the rates of $33 \mathrm{mmol} \mathrm{L}^{-1}$ of nitrogen and $11 \mathrm{mmol} \mathrm{L} 1$ of potassium. The leaf area which was measured by using the higher rates of nitrogen and potassium was $70 \%$ higher than that using the Hoagland \& Arnon (1950), typically $15 \mathrm{mmol} \mathrm{L}^{-1}$ of nitrogen and $6 \mathrm{mmol} \mathrm{L}^{-1}$ of potassium.

Lavres Jr. \& Monteiro (2003) found significant nitrogen $\times$ potassium interaction by two harvests of mombaçagrass. Using rates similar to those used in the present experiment, they reported that in the greater rates the leaf area was 11 times greater than in the smallest rates, and $22 \%$ greater than in those plants grown in Hoagland \& Arnon (1950) solution. Therefore, there is a need of adequate supply of nitrogen and potassium to grow tropical grasses using Hoagland \&Arnon (1950) solution.

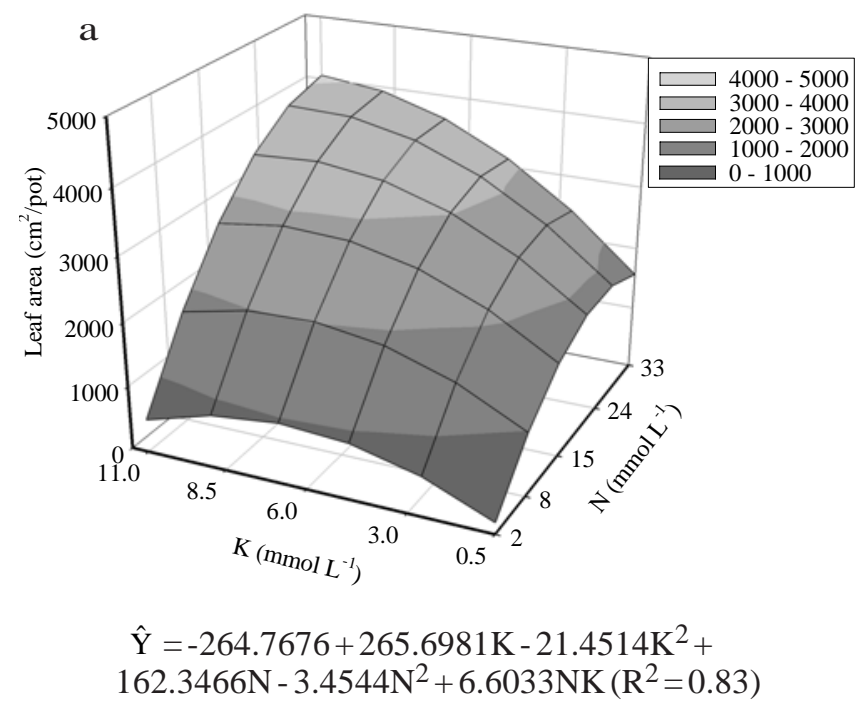

In the second harvest of marandu palisadegrass, the highest rate of nitrogen and potassium resulted in leaf area 20 times greater than that in the smallest rates, and 70\% greater than that using the Hoagland \& Arnon (1950) rates.

The leaf area in the higher rate combinations was greater at the second harvest, possibly because the root system was already established and the plant could use more resources to grow leaves and tillers, therefore increasing the leaf area.

Marschner (1995) observed that nitrogen supply may cause changes in plant morphology, including increase in leaf area. Chapmam \& Lemaire (1993) reported that nitrogen supply increased leaf length and area in grasses. Potassium is related to osmotic potential of cells so that influences for cell.

The analysis of morphology and nutrition of marandu palisadegrass showed that grass productivity was caused by leaves and tillers making it important to recover the leaf area in harvest conditions.

The nitrogen $\times$ potassium interaction was significant for the dry mass production of the shoots, both in the first and second harvests (Figure 4), and for the dry mass production of roots (Figure 5). The maximum production of dry mass for both shoot and root system would be achieved by using nitrogen and potassium rates greater than those tested in this experiment.

Figures $4 \mathrm{a}$ and $4 \mathrm{~b}$ show that from the lowest to the highest nitrogen and potassium rates, the dry mass production in the shoot increased 12 and 10 times, respectively. These results are in agreement with those by Monteiro et al. (1980), Cherney et al. (2004), Fitzpatrick \& Guilard (2004) and Lavres Jr. et al. (2004).

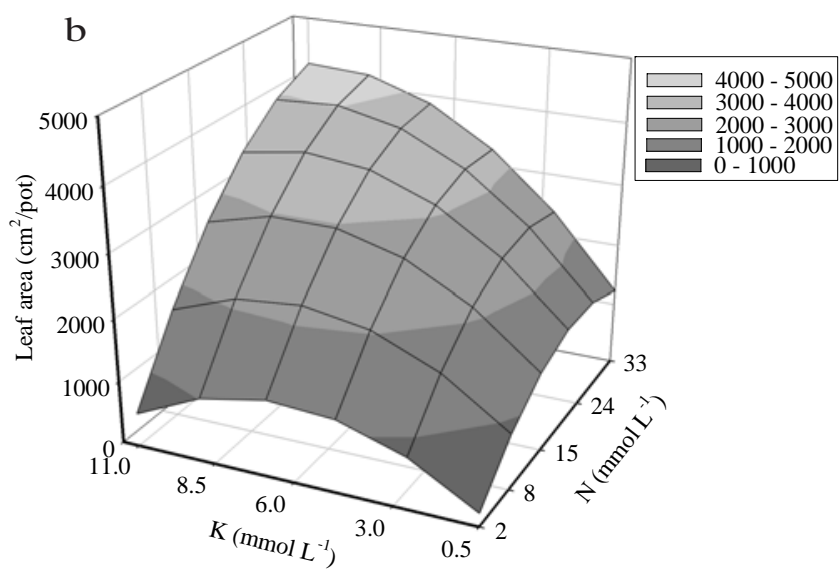

$$
\begin{gathered}
\hat{\mathrm{Y}}=-227.0241+371.2064 \mathrm{~K}-31.0888 \mathrm{~K}^{2}+133.1182 \mathrm{~N}- \\
2.9834 \mathrm{~N}^{2}+8.3139 \mathrm{NK}\left(\mathrm{R}^{2}=0.85\right)
\end{gathered}
$$

Figure 3 - Leaf area in the first (a) and second (b) harvests of marandu palisadegrass as related to combinations of nitrogen and potassium rates. 
When it was contrasted the lowest combination of nitrogen $\left(2 \mathrm{mmol} \mathrm{L}^{-1}\right)$ and potassium $\left(0.5 \mathrm{mmol} \mathrm{L}^{-1}\right)$ with the combination of $33 \mathrm{mmol} \mathrm{L}^{-1}$ of nitrogen and $0.5 \mathrm{mmol} \mathrm{L}^{-1}$ of potassium, it could not be observed a great change in the dry mass production of marandu palisadegrass shoot (Figure 4). This result agreed with the comment by Monteiro et al. (1980) about the need to check the potassium supply so it would not limit the response to nitrogen supply. Similar conclusions were also presented by Lavres Jr. \& Monteiro (2002) as they observed that $33 \mathrm{mmol} \mathrm{L}^{-1}$ of nitrogen coupled with low potassium rate such as $0.5 \mathrm{mmol}$ $\mathrm{L}^{-1}$ resulted in low dry mass production in the shoot of mombaçagrass different to the situation in which $33 \mathrm{mmol} \mathrm{L}^{-1}$ of nitrogen coupled with $11 \mathrm{mmol} \mathrm{L}^{-1}$ of potassium maximized the dry mass production of shoot. Similarly, Cherney et al. (2004) found low dry mass production in Phalaris arundinaceae L. even in greater nitrogen rates when coupled with low rates of potassium.

Fitzpatrick \& Guilard (2004) evaluated the recovery and efficiency of Kentucky bluegrass (Poa pratensis L.) in response to nitrogen and potassium rates. They found that, at low potassium rates, the nitrogen efficiency was $5 \mathrm{~g}$ of dry mass for each $g$ of nitrogen applied, while at the high potassium rates, the efficiency increased to more than $12 \mathrm{~g}$ of dry mass for each gram of nitrogen applied. In addition, the recovery of nitrogen in low potassium rates was about $30 \%$ while in the higher potassium rates it increased to $55 \%$. They also observed that great potassium rates help to decrease nitrogen pollution because of the better efficiency in its use by the plant.

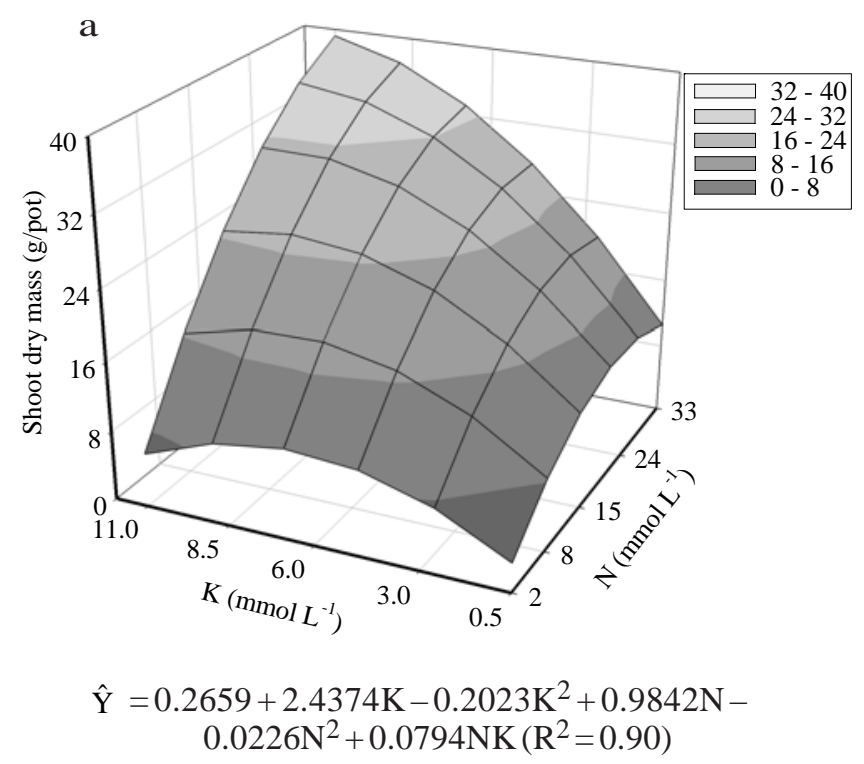

The greater dry mass production of the shoot, at the second harvest of marandu palisadegrass, resulted by using root resources to generate new tillers $(60 \%)$ and leaves (68\%). These resources were not available at the first plant growth. Such findings are in agreement with the great positive correlation between those variables and dry mass production of shoot (Table 1). Lavres Jr. \& Monteiro (2002) also reported a higher dry mass production of the shoot in the second harvest than in the first.

Plant growing process is essentially related to the capture of solar radiation, intercepted by the leaf area, which in turn is related to the number of tillers and leaves. Leaves are the main elements of the active photosynthetic area, and they are generated accordingly to the morphogenic program of the plant, influenced by environmental factors (Lemaire \& Chapman, 1996). Therefore, to increase the dry mass of shoot, it is needed the adequate nitrogen supply, coupled with potassium supply, aiming the maximum number of tillers and leaves.

The emergence and development of tillers and the related leaf population, therefore, is determinant for dry mass production in forage grasses (Lemaire \& Agnusdei, 2000). So, if there is an accessory bud for each new leaf, capable to originate a new tiller, the development of leaves can be considered as the main characteristic of morphogenesis, and the increase of dry mass as the sum of individual tillers in the plant.

By contrasting the lowest rates $\left(2 \mathrm{mmol} \mathrm{L}^{-1}\right.$ of nitrogen and $0.5 \mathrm{mmol} \mathrm{L}^{-1}$ of potassium) with the highest (33 $\mathrm{mmol} \mathrm{L}^{-1}$ of nitrogen and $11 \mathrm{mmol} \mathrm{L}^{-1}$ of potassium), the dry mass

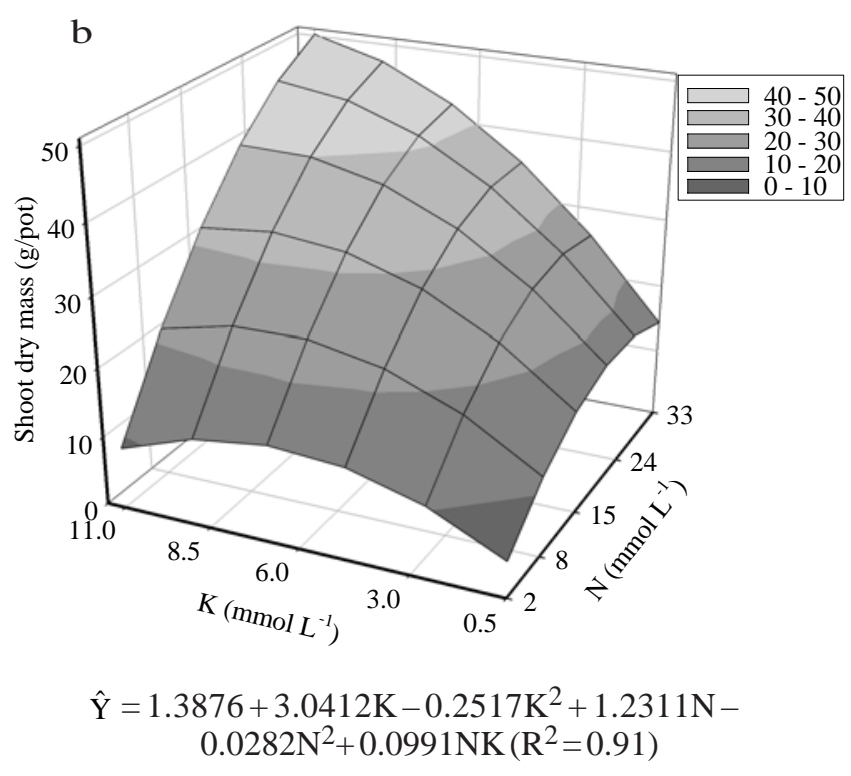

Figure 4 - Shoot dry mass production of marandu palisadegrass in first (a) and second (b) harvests as related to combinations of nitrogen and potassium rates. 
production increased 37 times, while the nitrogen and potassium rates recommended by Hoagland \& Arnon (1950) yielded $65 \%$ less dry mass than the highest rates used in this experiment. Marschner (1995) reported that the nutrient supply strongly changes growth and morphology of the root system. He also pointed out that among the nutrients, nitrogen is the one which influences at most, and ammonium increases the development of root system more than does nitrate. The lack of nitrogen deprives the development of the root system by accumulation of carbohydrates, according to Brower (1962).

Roots collected from the pots with low rates of potassium presented low dry mass and they were brittle and thin, easily destroyed, with a gelatinous aspect and strong smell of decomposition. Previous research of Ferrari Neto et al. (1994) with forage grasses concluded that the brittleness of roots was related to translocation of potassium from roots to the shoot during stages of intense growing, but it was insufficient to transport photosynthetic products back to the root system. According to these authors, the lack of potassium resulted in a significant decrease of shoot dry mass and particularly of the root system. Similar results were also found in the present experiment (Figure 5), confirming potassium as an important nutrient for root biomass increase.

Nitrogen and potassium are the nutrients absorbed at the largest amount by plants in the soil-root interface. This absorption process depends on the plant species, chemical characteristics of the soil solution, of the soil-root interface and the nutrition background of the plant (Subasinghe, 2006). It was previously reported that nitrate absorption stimulated potassium absorption (Zsoldos et al., 1990; Subasinghe, 2006).

When studying tanzaniagrass (Panicum maximumcv. Tanzânia), Monteiro \& Consolmagno (2008) concluded that the maximum dry mass of roots was obtained with the potassium rate of $8.4 \mathrm{mmol} \mathrm{L}^{-1}$ and magnesium rate of
$1.9 \mathrm{mmol} \mathrm{L}^{-1}$. The potassium demand was, probably, limited by the nitrogen rate of $15 \mathrm{mmol} \mathrm{L}^{-1}$. Potassium rate for maximum production of dry mass of roots would be greater in a nitrogen rate higher than that recommended by Hoagland \& Arnon (1950).

Potassium supply, regardless to the rate, is not sufficient to achieve large dry mass productivity of grasses if coupled with low rates of nitrogen. On the other hand, high rates of both potassium and nitrogen resulted in great dry mass productivity of both roots and shoots (Figures 4 and 5). Therefore, the results of this experiment agree with the idea that the adequate coupling of nitrogen and potassium rates are essential to achieve the maximum productivity of forage grasses.

By considering the maximum dry mass productivity of roots and shoots, the number of tillers and leaves, and leaf area, it is clear that the nitrogen and potassium rates recommended by Hoagland \& Arnon (1950) for the nutrient

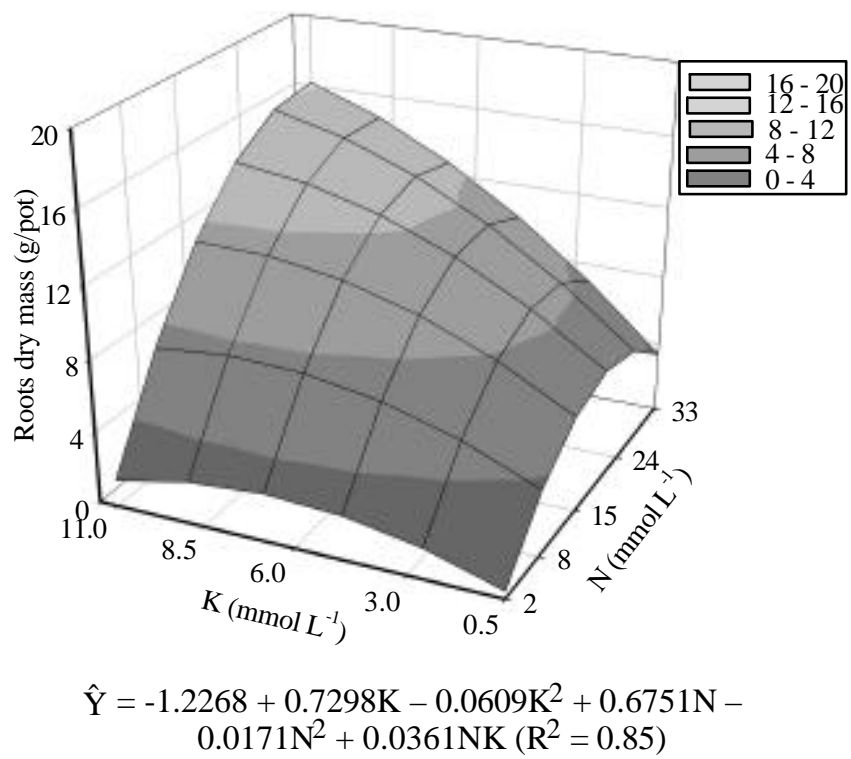

Figure 5 - Roots dry mass of marandu palisadegrass as related to combinations of nitrogen and potassium rates.

Table 1 - Correlation coeficients correlation of the Pearson between plant top dry mass, total number of tillers, total number of leaves and leaf area, in the first (1) and second (2) harvests of marandu palisadegrass, as related to combinations of nitrogen and potassium rates

\begin{tabular}{|c|c|c|c|c|c|c|c|c|}
\hline & $\begin{array}{c}\text { Shoot } \\
\text { dry mass } 1\end{array}$ & $\begin{array}{c}\text { Shoot } \\
\text { dry mass } 2\end{array}$ & $\begin{array}{l}\text { Number } \\
\text { tillers } 1\end{array}$ & $\begin{array}{l}\text { Number } \\
\text { tillers } 2\end{array}$ & $\begin{array}{l}\text { Number } \\
\text { leaves } 1\end{array}$ & $\begin{array}{l}\text { Number } \\
\text { leaves } 2\end{array}$ & $\begin{array}{l}\text { Leaf } \\
\text { area } 1\end{array}$ & $\begin{array}{l}\text { Leaf } \\
\text { area2 }\end{array}$ \\
\hline Shoot dry mass 1 & - & - & - & - & - & - & - & - \\
\hline Shoot dry mass 2 & $0.99 * * *$ & - & - & - & - & - & - & - \\
\hline Number tillers 1 & $0.94 * * *$ & $0.94 * * *$ & - & - & - & - & - & - \\
\hline Number tillers2 & $0.96 * * *$ & $0.96 * * *$ & $0.97 * * *$ & - & - & - & - & - \\
\hline Number leaves 1 & $0.92 * * *$ & $0.92 * * *$ & $0.98 * * *$ & $0.96 * * *$ & - & - & - & - \\
\hline Number leaves 2 & $0.96 * * *$ & $0.96 * * *$ & $0.98 * * *$ & $0.99 * * *$ & $0.96 * * *$ & - & - & - \\
\hline Leaf area 1 & $0.98 * * *$ & $0.98 * * *$ & $0.95 * * *$ & $0.95 * * *$ & $0.96 * * *$ & $0.95 * * *$ & - & - \\
\hline Leaf area2 & $0.99 * * *$ & $0.99 * * *$ & $0.96 * * *$ & $0.95 * * *$ & $0.95 * * *$ & $0.98 * * *$ & $0.98 * * *$ & - \\
\hline
\end{tabular}

*** Significant at $0.1 \%$ probability 
solution were not sufficient to Brachiaria brizantha Stapf. cv. Marandu express its whole potential of productivity, which would require higher rates of nitrogen and potassium.

The nitrogen $\times$ potassium interaction was significant for root total length and root specific length were significant (Figure 6). At the smallest supply of nitrogen $\left(2 \mathrm{mmol} \mathrm{L}^{-1}\right)$ and potassium $\left(0.5 \mathrm{mmol} \mathrm{L}^{-1}\right)$, the total root length was $99 \mathrm{~m}$ per pot, while at the greatest supply (33 mmol L-1 of nitrogen and $11 \mathrm{mmol} \mathrm{L}^{-1}$ of potassium) it was $141 \mathrm{~m}$. The highest nitrogen rate $\left(33 \mathrm{mmol} \mathrm{L}^{-1}\right)$ coupled with the lowest potassium rate $\left(0.5 \mathrm{mmol} \mathrm{L}^{-1}\right)$ resulted in a total root length of $685 \mathrm{~m}$, which indicated that when the plant suffers deficiency the root system reaches its maximum length.

Lavres Jr. \& Monteiro (2003) also reported an 80\% increase in the length of the root system when the lowest and the highest rates of nitrogen and potassium in mombaçagrass were compared. For reaching the maximum root length, those authors concluded that it would be needed the highest rates of nitrogen and $11 \mathrm{mmol} \mathrm{L}^{-1}$ of potassium (which is a rate $5 \mathrm{mmol} \mathrm{L}^{-1}$ greater than that recommended by Hoagland \& Arnon, 1950). This is also in agreement with Marschner (1995), that nitrogen is the main nutrient controlling the root system growth.

Batista \& Monteiro (2006) studied combinations of nitrogen and sulfur in marandu palisadegrass and observed that the interaction between rates of these two nutrients was not significant for the total root length, which depended only on the nitrogen rate, and the maximum length was

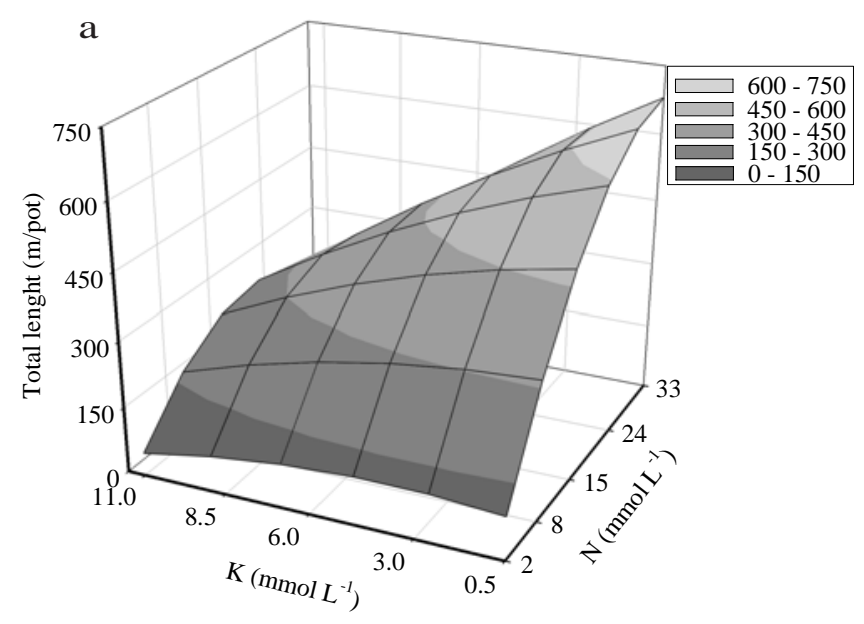

$\hat{\mathrm{Y}}=14.0626+11.4474 \mathrm{~K}-1.1157 \mathrm{~K}^{2}+41.7303 \mathrm{~N}-$ $0.6341 \mathrm{~N}^{2}-1.5369 \mathrm{NK}\left(\mathrm{R}^{2}=0.90\right)$ obtained with $29 \mathrm{mmol} \mathrm{L}^{-1}$. These authors also reported an increase of 8.4 times when compared the lowest $\left(1 \mathrm{mmol} \mathrm{L}^{-1}\right)$ nitrogen rate with the rate to produce maximum root length. This is also in agreement with the reported by Marschner (1995) that the nutrient supply has an extensive impact on the growth and morphology of roots.

The specific root length (the ratio between the total root length and the root dry mass) had the minimum value at the highest rates of nitrogen and potassium (Figure 6b). The specific root length decreased as the potassium rates increased, meaning a greater average root diameter (thicker roots) and agreed with the findings by Fitter (1996), Lavres Jr. \& Monteiro (2003) and Batista \& Monteiro (2006), in which great values of specific root length mean that roots are searching for nutrients.

The nitrogen $\times$ potassium interaction was significant for total root surface and root specific surface (Figure 7). The total root surface was 7.2 times greater in the highest nitrogen and potassium rates as compared to the lowest rates. Using the same reasoning for root surface, the increase was 9.6 times. Contrasting the rates recommended by Hoagland \& Arnon (1950) (15 mmol L-1 of nitrogen and $6 \mathrm{mmol} \mathrm{L}^{-1}$ of potassium) with the highest rates of nitrogen and potassium, the root surface was 1.6 times smaller in the Hoagland \& Arnon (1950) solution.

Lavres Jr. \& Monteiro (2003) found an increase of 6 times in root surface for the highest nitrogen and potassium rates when compared with the lowest rates, and when the highest rates were compared to the Hoagland \& Arnon (1950) solution, there was an increase of 68\%. Batista \& Monteiro (2006)

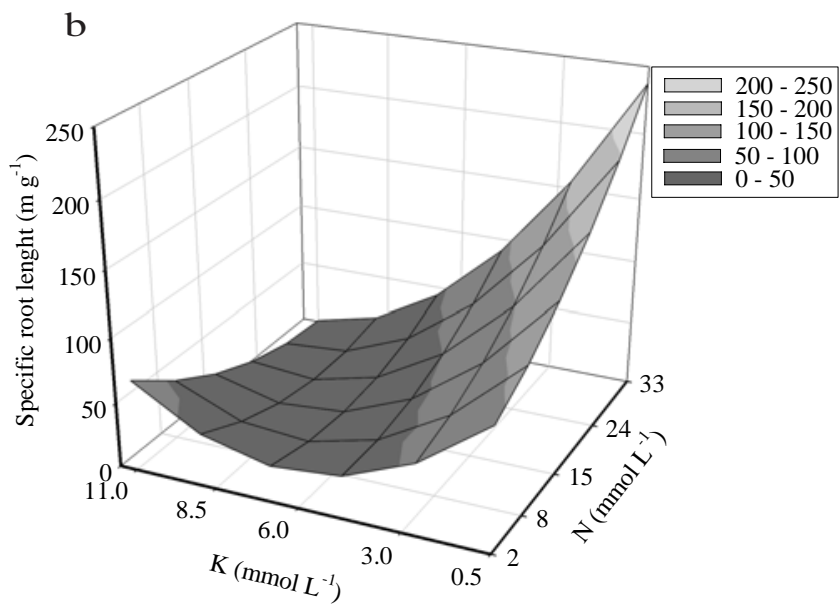

$$
\begin{gathered}
\hat{\mathrm{Y}}=102.0054-23.7705 \mathrm{~K}+1.9783 \mathrm{~K}^{2}+2.3524 \mathrm{~N}+ \\
0.0735 \mathrm{~N}^{2}-0.6519 \mathrm{NK}\left(\mathrm{R}^{2}=0.76\right)
\end{gathered}
$$

Figure 6 - Total root length (a) and specific root length (b) of marandu palisadegrass as related to combinations of nitrogen and potassium rates. 

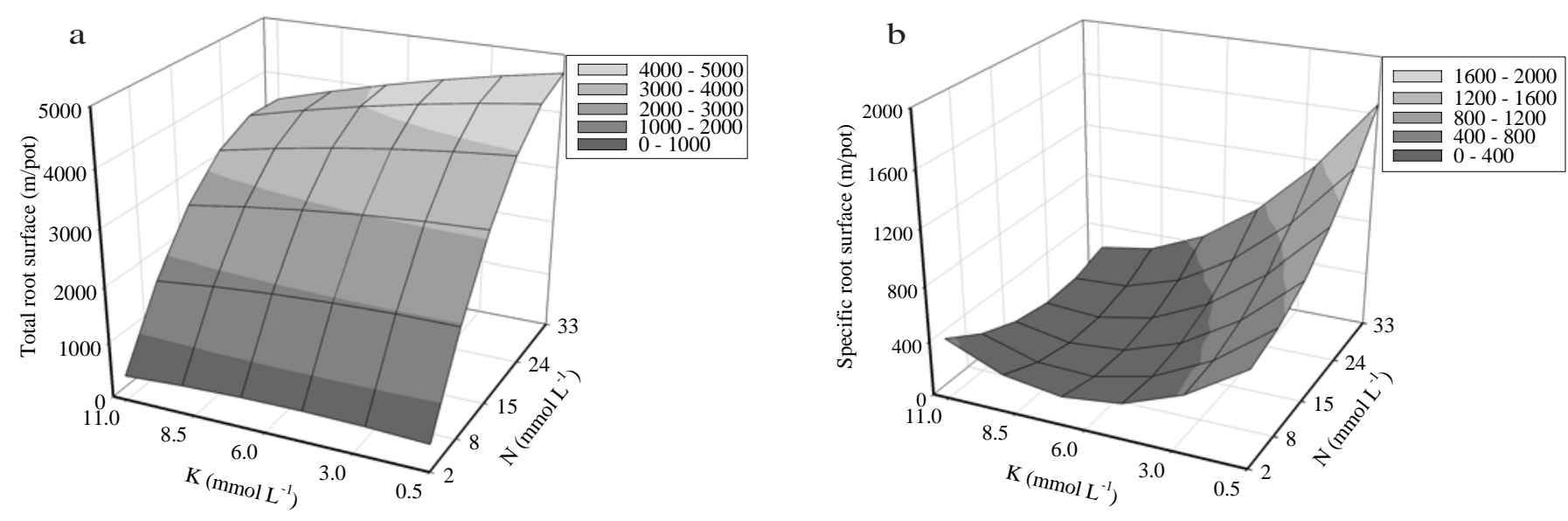

$$
\begin{gathered}
\hat{\mathrm{Y}}=-72.2566+37.3808 \mathrm{~K}-2.9806 \mathrm{~K}^{2}+281.8891 \mathrm{~N}- \\
4.1377 \mathrm{~N}^{2}-3.4789 \mathrm{NK}\left(\mathrm{R}^{2}=0.87\right)
\end{gathered}
$$

$$
\begin{array}{r}
\hat{\mathrm{Y}}=765.8064-163.2178 \mathrm{~K}+12.7613 \mathrm{~K}^{2}+5.4893 \mathrm{~N} \\
+0.7904 \mathrm{~N}^{2}-3.7019 \mathrm{NK}\left(\mathrm{R}^{2}=0.70\right)
\end{array}
$$

Figure 7 - Total root surface (a) and specific root surface (b) of marandu palisadegress as related to combinations of nitrogen and potassium rates.

reported the benefit of nitrogen rates to the root surface of marandu palisadegrass, whose response could be adjusted to a quadratic regression equation, and the estimatedpoint of maximum root surface was at $32 \mathrm{mmol} \mathrm{L}^{-1}$ nitrogen.

The specific root surface (ratio between total root surface and dry root mass) reached the minimum value at the combination of greatest nitrogen and potassium rates (Figure 7b). When potassium was supplied at the lowest rates, keeping the nitrogen at the highest rates, an increase up to four times in the specific surface was observed, when comparing to the highest potassium rate. Lavres Jr. \& Monteiro (2003) did not find any nitrogen $\times$ potassium significant interaction for specific surface of mombaçagrass, which was influenced both by nitrogen and potassium rates. The points of minimum root specific surface were $21 \mathrm{mmol} \mathrm{L}^{-1}$ of nitrogen and $7 \mathrm{mmol} \mathrm{L}^{-1}$ of potassium.

The root system development was strongly modified by the variations in nitrogen and potassium rates in the nutrient solution. It can be observed in Figures 5, 6 and 7 that the nitrogen supply depended on the combination with the potassium supply and influenced the development of root system, and the rates recommended by Hoagland \& Arnon (1950) did not satisfy the need of the root system, as measured by the root characteristics.

\section{Conclusions}

The combinations of nitrogen and potassium rates cause changes in the morphological and productivity characteristics of Brachiaria brizantha Stapf. cv. Marandu.
Nitrogen and potassium rates needed to maximize the morphological and productivity characteristics of marandu palisadegrass are greater than those recommended by Hoagland \& Arnon (1950). The rates that maximize the morphogenic and productive characteristics of marandu palisadegrass are 30 and 9, and 33 and $11 \mathrm{mmol} \mathrm{L}^{-1}$, respectively.

\section{References}

ALEXANDRINO, E.; NASCIMENTO JR., D.; REGAZZI, A. Características morfogênicas e estruturais da Brachiaria brizantha cv. Marandu submetida a diferentes doses de nitrogênio e freqüências de cortes. Acta Scientiarum Agronomy, v.27, p.17-24, 2005.

AUDA, H.; BLASER, R.E.; BROWN, R.H. Tillering and carbohydrate contents of orchargrass as influenced by environmental factors. Crop Science, v.6, p.139-143, 1976.

BATISTA, K.; MONTEIRO, F.A. Sistema radicular do capimmarandu considerando as combinações de doses de nitrogênio e de enxofre. Revista Brasileira de Ciência do Solo, v.30, p.821-828, 2006.

BROWER, R. Nutritive influences on the distribution of dry matter in the plant. Journal of Agricultural Science, v.10, p.342-399, 1962.

CARVALHO, M.M.; MARTINS, C.E.; VERNEQUE, R.S. et al. Respostas de uma espécie de Brachiaria à fertilização com nitrogênio e potássio em um solo ácido. Revista Brasileira de Ciência do Solo, v.15, p.195-200, 1991.

CHAPMAN, D.F.; LEMAIRE, G. Morphogenetic and structural determinants of plant regrowth after defoliation. In: INTERNATIONAL GRASSLAND CONGRESS, 17., 1993, Palmerston North. Proceedings... Palmerston North: New Zealand Grassland Association, 1993. p.95-104.

CHERNEY, J.H.; KETTERINGS, Q.M.; ORLOSKI, J.L. Plant and soil elemental status as influenced by multi-year nitrogen and potassium fertilization. Journal of Plant Nutrition, v.27, p.991-1014, 2004. 
CORSI, M. Pastagens de alta produtividade. In: SIMPÓSIO SOBRE MANEJO DA PASTAGEM, 8., 1986, Piracicaba. Anais... Piracicaba: FEALQ, 1986. p.499-512.

CRESTANA, S.; GUIMARÃES, M.S.; JORGE, L.A.C. et al. Avaliação da distribuição de raízes no solo auxiliada por processamento de imagens digitais. Revista Brasileira de Ciência do Solo, v.18, p.365-371, 1994.

FERRAGINE, M.D.C.; MONTEIRO, F.A. Combinações de doses de nitrogênio e potássio na nutrição mineral de capim-Braquiária. Boletim de Indústria Animal, v.56, p.25-33, 1999.

FERRAGINE, M.D.C.; MONTEIRO, F.A.; SILVA, S.C. Leaf appearance rate in Brachiaria decumbens grown in nitrogen and potassium rates. In: INTERNATIONAL GRASSLAND CONGRESS, 19., 2001, São Pedro. Proceedings... Piracicaba: FEALQ, 2001. p.69-70.

FERRARI NETO, J.; FAQUIN, V.; VALE, F.R. Limitações nutricionais do colonião Panicum maximum Jacq.) e da braquiária (Brachiaria decumbens Stapf.), em amostras de um Latossolo do noroeste do Paraná: I. Produção de matéria seca e perfilhamento. Revista Brasileira de Zootecnia, v.23, n.4, p.538-551, 1994.

FITTER, A. Characteristics and functions of root systems. In: WAISEL, Y.; ESHEL, A.; KAFKAFI, U. (Eds.) Plant roots: the hidden half. New York: Marcel Dekker, 1996. p.1-20.

FITZPATRICK, R.J.M.; GUILLARD, K. Kentucky Bluegrass response to potassium and nitrogen fertilization. Crop Science, v.44, p.1721-1728, 2004.

HOAGLAND, D.; ARNON, D.I. The water culture method for growing plants without soil. Ona: California Agriculture Experimental Station Circular, 1950. 347p.

LANGER, R.H.M. Tillering in herbage grasses. Herbage Abstracts, v.33, p.141-148, 1963.

LAUDE, H.M. External factors tiller development. In: YOUNGNER, V.B.; McKELL, C.M. (Eds.) The biology and utilization of grasses. New York: Academic Press, 1972. p.146-154.

LAVRES JR., J.; MONTEIRO, F.A. Combinações de doses de nitrogênio e potássio para a produção e nutrição do capim-mombaça. Boletim de Indústria Animal, v.59, p.101-114, 2002.

LAVRES JR., J.; MONTEIRO, F.A. Perfilhamento, área foliar e sistema radicular do capim-mombaça submetido a combinações de doses de nitrogênio e potássio. Revista Brasileira de Zootecnia, v.32, p.1068-1075, 2003.

LAVRES JR., J.; FERRAGINE, M.D.C.; GERDES, L. et al. Yield and morphogenesis of Aruana grass as related to nitrogen supply. Scientia Agricola, v.61, p.632-639, 2004.

LEMAIRE, G.; AGNUSDEI, M. Leaf tissue turn-over and efficiency of herbage utilization. In: LEMAIRE, G., HODGSON, J., MORAES, A. (Eds.) Grassland ecophysiology and grazing ecology. Wallingford: Cab international, 2000. p.265-288.

LEMAIRE, G.; CHAPMAN, D. Tissue fluxes in grazing plant communities. In: HODGSON, J.; ILLIUS, A.W. (Eds.). The ecology and management of grazing systems. Wallingford: Cab International, 1996. p.3-36.

LITTELL, R.C.; MOTT, G.O. Computer assisted design and analysis of response surface experiments in agronomy. Soil and Crop Society of Florida Proceedings, v.34, p.94-97, 1975.

MARSCHNER, H. Mineral nutrition of higher plants. 2.ed. London: Academic Press, 1995. 889p.

MATTOS, W.T.; MONTEIRO, F.A. Respostas de Brachiaria brizantha a doses de potássio. Scientia Agricola, v.55, p.428-437, 1998.
McKENZIE, F.R. The influence of applied nitrogen on the vigour of Lolium perenne during the establishment year under subtropical conditions. Tropical Grasslands, v.30, p.249-345, 1996.

MESQUITA, E.E.; NERES, M.A. Morfogênese e composição bromatológica de cultivares de Panicum maximum em função da adubação nitrogenada. Revista Brasileira de Saúde e Produção Animal, v.9, n.2, p.201-209, 2008.

MONTEIRO, F.A.; CONSOLMAGNO NETO, D. Sistema radicular do capim-tanzânia adubado com potássio e magnésio. Revista Brasileira de Zootecnia, v.37, n.5, p.810-818, 2008.

MONTEIRO, F.A.; LIMA, S.A.A.; WERNER, J.C. et al. Adubação potássica em leguminosas e em capim-colonião (Panicum maximum Jacq.) adubado com níveis de nitrogênio ou consorciado com leguminosas. Boletim de Indústria Animal, v.37, p.127-148, 1980.

MONTEIRO, F.A.; RAMOS, A.K.B.; CARVALHO, D.D. et al. Cultivo de Brachiaria brizantha cv. Marandu em solução nutritiva com omissões de macronutrientes. Scientia Agricola, v.52, p.135-141, 1995.

NABINGER, C. Princípios da exploração intensiva de pastagens. In: PEIXOTO, A.M.; MOURA, J.C.; FARIA, V.P. (Eds.) Produção de bovinos a pasto. Piracicaba: Fundação de Estudos Agrários "Luiz de Queiroz", 1996. p.15-95.

NABINGER, C.; MEDEIROS, R.B. Produção de sementes de Panicum maximum. In: SIMPÓSIO SOBRE MANEJO DA PAStagem, 14., 1992, Piracicaba. Anais... Piracicaba: FEALQ, 1995. p.59-128.

NELSON, C.J.; ZARROUGH, K.M. Tiller density and tiller weight as yield determinants of vegetative swards. In: WRIGTH, C.E (Ed.). Plant physiology and herbage production. Hurley: British Grassland Society, 1981. p.25-29.

PINTO, J.C.; GOMIDE, J.A.; MAESTRI, M. Produção de matéria seca e relação folha/caule de gramíneas forrageiras tropicais, cultivadas em vaso, com duas doses de nitrogênio. Revista da Sociedade Brasileira Zootecnia, v.23, p.313-326, 1994.

ROSSIELlO, R.O.P.; ARAÚJO, A.P.; MANZATTO, C.V. et al. Comparação dos métodos fotoelétrico e da interseção na determinação de área, comprimento e raio médio radicular. Pesquisa Agropecuária Brasileira, v.30, p.633-638, 1995.

RUGGIERI, A.C.; FAVORETTO, V.; MALHEIROS, E.B. Características de crescimento e produção de matéria seca da Brachiaria brizantha (Hochst) Stapf. cv. Marandu em função de níveis de nitrogênio e regimes de corte. Boletim de Indústria Animal, v.51, p.149-155, 1994.

RYLE, G.J.A. Effects of two levels of applied nitrogen on the growth of S27 cocksfoot in small simulated swards in a controlled environment. Journal of British Grassland Society, v.25, p.20-29, 1970.

STATISTICAL ANALYSIS SYSTEM - SAS. The SAS-system for windows: release 6.08 (software). Cary: SAS Institute, 1996. (CD-ROM).

SUBASINGHE, R. Effects of nitrogen and potassium stress and cultivar differences on potassium íons and nitrate uptake in sugarcane. Journal of Plant Nutrition, v.29, p.809-825, 2006.

VICENTE-CHANDLER, J.; PEARSON, R.W.; ABRUÑA, F. et al. Potassium fertilization of intensive managed grasses under humid tropical conditions. Agronomy Journal, v.54, p.450-453, 1962.

ZSOLDOS, F.; HAUNOLD, E.; HERGER, P. et al. Effects of sulfate and nitrate on $\mathrm{K}^{+}$uptake and growth of wheat and cucumber. Physiologia Plantarum, v.80, p.425-430, 1990. 